\title{
The Effect of Bamboo Dance Learning Model on Interest and Learning Achievement of Social Sciences Class III SDN 2 Temulus
}

\author{
Yulina Ismiyanti \\ Universitas Islam Sultan Agung, Jl. Kaligawe Raya No.KM. 4, Terboyo Kulon, Kec. \\ Genuk, Kota Semarang, Jawa Tengah 50112 \\ \{yulinaismiyanti@unissula.ac.id\}
}

\begin{abstract}
The purpose of this study was to determine the effect of bamboo dance learning models on the interest and learning achievement of Social Sciences Class III SDN 2 Temulus. This type of research is Quasi Experiment of Nonequivalent Control Group Desaign. The sample of this study refers to Krejcie and Morgan's table, with a level of error of $5 \%$ obtained a number of samples VA 24 and VB 24. Data collection techniques in this study used student achievement tests and questionnaires. The data obtained were analyzed using the Multivariate Test. There is a significant influence between the bamboo dance learning model on student interest and learning achievement in the experimental class and the control class. And there is a significant difference between the bamboo dance learning model and the students' achievement and interest in the experimental class and the control class.
\end{abstract}

Keywords: Bamboo Dance Learning Model, Interest, and Learning Achievement

\section{Introduction}

Based on observations at SDN Temulus 02 with grade III shows that student learning outcomes have not been achieved, due to very low student interest in learning. At the time of learning activities the teacher has not used a learning model that can attract students' interest. Students generally lack interaction with friends when learning takes place so students tend to be silent and only pay attention to explanations from the teacher without giving students the opportunity to exchange ideas that students have, because teachers still use conventional models in the delivery of learning material. Therefore we need a model to foster student interest in thematic learning. Lack of student interest in thematic lessons is evidenced by low creativity and cooperation which results in students getting bored easily during learning. This is evidenced by the daily test scores of students who on average are still many students who get scores below the minimum completeness criteria.

The alternative chosen is through the bamboo dance model. The bamboo dancing cooperative learning model is a learning model that provides opportunities for students to play an active role and interact with other students maximally, so that information exchange occurs between students. Learning begins with an introduction to the topic by the teacher. The 
teacher writes down the topic on the board or conducts questions and answers with students. Question and answer activities are carried out to activate the cognitive structures that students have so that they are better prepared to face new lessons [1]. Interaction in learning is said to be maximum if there is an interaction between the teacher and all students as well as students and students to achieve the goals that have been set together [2]. The advantage of the bamboo dancing cooperative learning model is that students share information with different partners in a short and regular time. so that they have many opportunities to process information and improve communication skills. All students are expected to be actively involved in providing and receiving information with their friends [3].

When students have an interest in learning, students will always actively participate in learning and will give good achievements in learning achievement. According to Slameto [4], indicators of interest in learning are: pleasure, interest, acceptance, and student involvement. Learning achievement is the peak of learning outcomes achieved by students within a certain period of time which is expressed in the form of numbers, letters, symbols and sentences and results in changes in students both changes in knowledge, attitudes and skills as a result of activities in learning. In this study, learning achievement is limited to the cognitive aspects. The formulations of the problems in this study are: (1) Does the bamboo dance learning model affect the interest and learning achievement of grade III students of SDN 02 Temulus? (2) Are there any differences before and after using the bamboo dance learning model on the interest and learning achievement students in grade III of SDN 02 Temulus?

The research carried out is expected to provide theoretical and practical benefits. This research is expected to contribute knowledge in the field of education, especially elementary thematic learning through the bamboo dance learning model. This research can also be used as a reference for future researchers in the same research but in a broader and deeper scope. For teachers, to increase teacher creativity in teaching through the bamboo dance learning model. The use of the bamboo dance model makes students get a direct learning experience so that learning is more enjoyable. This research can improve the quality of learning in schools through the application of learning models. The hypotheses in this study are: (1) There is an effect of the bamboo dance learning model on student interest and achievement. (2) There are differences in student interest and learning achievement before and after using the bamboo dance learning model.

\section{Research methods}

This research is a type of research in the form of an experiment. Experimental research is one of the research processes carried out to get an influence on an action (experimental group) with a comparison group (control group). The research design used was quasi experimental and used a nonequivalent control group design model. This design has a control group, but it cannot fully function to control the broad variables that have an experimental implementation.

\subsection{Population}

The population in this study were students of class IIIA and IIIB SDN Temulus 02. the number of class IIIA which consists of 10 male students and 15 female students. Meanwhile, class IIIB consists of 8 male students and 17 female students. The total number of students in class III is 50 students. 


\subsection{Sample}

In determining the sample, this study refers to the number of samples table based on the Krejcie and Morgan tables with an error rate of 5\%. If the number of initial population with the number of students in class IIIA 25 and class IIIB 25 then the number of samples is taken based on the Krejcie and Morgan tables, if the initial population is 25 students then it is taken to be 24 students per class from the initial population and also obtained a sample of: IIIA 24 and IIIB 24 and the sum of all samples becomes 48 .

\subsection{Data Collection Techniques}

Questionnaires were given to all students to be filled out individually. This questionnaire was given to determine students' interest in learning. Learning achievement tests are given to all students to determine student cognitive achievement.

\subsection{Data Analysis Techniques}

\section{a) Normality test}

Based on this characteristic, checking the multinormal distribution can be done by means of a q-q plot.

\section{b) Homogeneity Test}

Several multivariate statistical analyzes such as discriminant analysis and MANOVA require homogeneous variance-covariance matrix requirements. To test this requirement, the Box-M test statistics can be used. Hypotheses and Box-M test statistics are [5].

\section{c) Final Data Analysis (MANOVA)}

Multivariate analysis of variance is a translation of the multivariate analysis of variance (MANOVA). MANOVA is a variant difference test, different from ANOVA compared to one dependent variable, whereas in MANOVA, the variants compared come from more than one dependent variable.

After determining the value, the rules for determining the test results are based on Fcount which means:

a) If the significant level is $\leq$ value $\alpha 0.05$ then $\mathrm{H} 0$ is accepted and Ha is rejected, which means that the average of the two treatments has a significant similarity.

b) If the significant level $\geq \alpha$ value 0.05 then $\mathrm{H} 0$ is rejected and $\mathrm{Ha}$ is rejected, which means that the average of the two treatments has a significant difference.

\section{Research Result}

The preliminary data analysis was obtained from the pretest scores of class IIIA and IIIB students of SDN 02 Temulus. Initial data analysis, preliminary data analysis proved that the data were normally distributed and homogeneous. The experimental class was given learning 
with the bamboo dance learning model and the control class was given learning using the conventional model.

\subsection{Normality test}

The normality test aims to test whether in the data, the dependent variable with the independent variable both has a normal distribution relationship or not. Good data is having a normal or near normal data distribution [6].

Table 1. Tests of Normality

\begin{tabular}{lccccccc}
\hline & Class & \multicolumn{3}{c}{ Kolmogorov-Smirnov } & \multicolumn{3}{c}{ Shapiro-Wilk } \\
\cline { 3 - 8 } & & Statistic & Df & Sig. & Statistic & Df & Sig. \\
\hline Control & Class A & .155 & 24 & .139 & .918 & 24 & .052 \\
& Class B & .348 & 24 & .000 & .666 & 24 & .099 \\
Eksperiment & Class A & .299 & 24 & .000 & .649 & 24 & .091 \\
& Class B & .533 & 24 & .000 & .316 & 24 & .081 \\
\hline
\end{tabular}

The normality test table above shows the significance value of class A and class B above the critical value of 0.05 . This shows that the data is normally distributed and can be continued to the next stage.

\subsection{Homogeneity test}

The homogeneity test is used to determine whether the data from the research results in the experimental class and control class have the same variant value or not. It is said to have the same / not different (homogeneous) variant value if the significance level is $\geq 0.05$ and if the significance level is $<0.05$ then the data is concluded not to have the same / different (not homogeneous) variant values.

Table 2. Box's Test of Equality of Covariance Matrices ${ }^{\mathrm{a}}$

\begin{tabular}{cc}
\hline Box's M & 78.289 \\
F & 24.867 \\
df1 & 3 \\
df2 & 380880.000 \\
Sig. & .120 \\
\hline
\end{tabular}

Tests the null hypothesis that the observed covariance matrices of the dependent variables are equal across groups.

Table 3. Levene's Test of Equality of Error Variances ${ }^{\mathrm{a}}$

\begin{tabular}{ccccc}
\hline & F & df1 & df2 & Sig. \\
\hline Control Class & .396 & 1 & 46 & .532 \\
Eksperiment Class & 22.041 & 1 & 46 & .345 \\
\hline
\end{tabular}

Tests the null hypothesis that the error variance of the dependent variable is equal across groups. From the results of the calculation of the homogeneity test contained in the Box's Test of Equality of Covariance Matricesa, it is known that the Box's M test value is 78,289 with a significance level of 0.120 , so the data has the same / no different (homogeneous) variant value. 


\subsection{Multivariate Test}

There are basically two parts of MANOVA output, namely the MultivariateTest output which states whether there is a real difference between groups, and the Between Subject Effect output which tests each variable individually.

Table 4. Multivariate Tests ${ }^{\mathrm{b}}$

\begin{tabular}{llccccc}
\hline Effect & & Value & F & Hypothesis df Error df & Sig. \\
\hline \multirow{3}{*}{ Intercept } & Pillai's Trace & .998 & $10260.654^{\mathrm{a}}$ & 2.000 & 45.000 & .000 \\
& Wilks' Lambda & .002 & $10260.654^{\mathrm{a}}$ & 2.000 & 45.000 & .000 \\
& Hotelling's Trace & 456.029 & $10260.654^{\mathrm{a}}$ & 2.000 & 45.000 & .000 \\
& Roy's Largest Root & 456.029 & $10260.654^{\mathrm{a}}$ & 2.000 & 45.000 & .000 \\
& Pillai's Trace & .178 & $4.885^{\mathrm{a}}$ & 2.000 & 45.000 & .012 \\
Kelas & .822 & $4.885^{\mathrm{a}}$ & 2.000 & 45.000 & .012 \\
& Wilks' Lambda & .217 & $4.885^{\mathrm{a}}$ & 2.000 & 45.000 & .012 \\
& Hotelling's Trace & .217 & $4.885^{\mathrm{a}}$ & 2.000 & 45.000 & .012 \\
& Roy's Largest Root & .217 & & & & \\
\hline
\end{tabular}

Based on the output of the Multivariate tests above, the significant value is seen in Pillai's Trace, Wilks' Lambda, Hotelling's Trace, and Roy's Largest Root which are in the class effect and the overall result is equal to 0.012 with the $\mathrm{F}$ test for Hotelling Trace of 4.885 . The significant value is less than 0.05 , so according to the decision making criteria $\mathrm{H} 0$ is rejected. This means that there is a significant influence between project based learning and these two variables, namely creativity and student cooperation. Furthermore, to determine the effect of individual variables, it can be seen in the Between-Subjects Effects table.

Table 5. Tests of Between-Subjects Effects

\begin{tabular}{|c|c|c|c|c|c|c|c|}
\hline Source & Dependen & t Variable & $\begin{array}{l}\text { ype III Sum of } \\
\text { Squares }\end{array}$ & Df & Mean Square & $\mathbf{F}$ & Sig. \\
\hline \multirow[t]{2}{*}{ Corrected Model } & \multirow{2}{*}{ dimension1 } & Control & $82.687^{\mathrm{a}}$ & 1 & 82.687 & 5.471 & .024 \\
\hline & & Eksperiment & $25.521^{\mathrm{b}}$ & 1 & 25.521 & 6.914 & .012 \\
\hline \multirow[t]{2}{*}{ Intercept } & \multirow[b]{2}{*}{ dimension1 } & Control & 64021.021 & 1 & 64021.021 & 4235.585 & .000 \\
\hline & & Eksperiment & 73711.688 & 1 & 73711.688 & 19969.988 & .000 \\
\hline \multirow[t]{2}{*}{ Kelas } & \multirow{2}{*}{ dimension1 } & Control & 82.688 & 1 & 82.688 & 5.471 & .024 \\
\hline & & Eksperiment & 25.521 & 1 & 25.521 & 6.914 & .012 \\
\hline \multirow[t]{2}{*}{ Error } & \multirow{2}{*}{ dimension1 } & Control & 695.292 & 46 & 15.115 & & \\
\hline & & Eksperiment & 169.792 & 46 & 3.691 & & \\
\hline \multirow[t]{2}{*}{ Total } & \multirow{2}{*}{ dimension1 } & Control & 64799.000 & 48 & & & \\
\hline & & Eksperiment & 73907.000 & 48 & & & \\
\hline \multirow[t]{2}{*}{ Corrected Total } & \multirow{2}{*}{ dimension 1} & Control & 777.979 & 47 & & & \\
\hline & & Eksperiment & 195.312 & 47 & & & \\
\hline
\end{tabular}

a. $\mathrm{R}$ Squared $=, 106$ (Adjusted R Squared $=, 087$ )

b. R Squared $=, 131$ (Adjusted R Squared $=, 112$ )

Based on the table above on the variable value of student cooperation, a significant number is obtained $0.024<0.05$. That is, with the $\mathrm{F}$ test value between project based learning and student collaboration of 5.471, there is a difference between student cooperation in the experimental class and the control class of 0.024 . Whereas in the variable value of creativity, the significance value obtained is $0.012<0.05$. This means that with the value of $F$ test between project based learning with creativity of 6.914, there is a significant difference in the value of student creativity between the experimental class and the control class of 0.012 . 


\section{Acknowledgements}

I would like to express my gratitude and appreciation to the Dean of the Teaching and Education Faculty for his support so that I can participate in this international seminar. To all those who cannot be mentioned one by one, I would like to say thank you and my highest appreciation.

\section{References}

[1] Istarani: Teori Perkembangan Kognitif. Vol. 2, pp. 10-11. Legally Free Computer Books, US (2013).

[2] Miterianifa: Model Pembelajaran Kooperatif. Widya Pustaka, Semarang (2013).

[3] Lie, Anita: Model Pembelajaran Aktif. Sinar Jaya Press, Yogyakarta (2013).

[4] Slameto: Manajemen Kelas, Wijaya Kusuma Press, Yogyakarta (2013).

[5] Rencher: Analisis Data Penelitian. Vol. 2, pp. 10-11. Legally Free Computer Books, US (1995).

[6] Ghozali: Analisis data Penelitian Pendidikan, Pustaka Prima, Solo (2001). 